Full Length Article

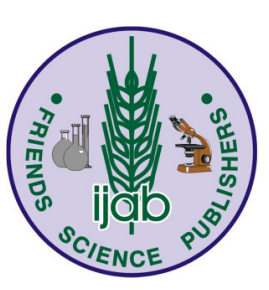

\title{
Biological and Molecular Characterization of Cucumber green mottle mosaic virus Affecting Bottle Gourd and Watermelon Plants in Saudi Arabia
}

\author{
Mahmoud Ahmed Amer \\ Plant Protection Department, College of Food and Agricultural Sciences, King Saud University, P. O. Box 2460, Riyadh \\ 11451, Saudi Arabia and Virus and Phytoplasma Research Department, Plant Pathology Res. Inst., Agric. Res. Center, Egypt \\ For correspondence: ruamerm@ksu.edu.sa; mamaamery@yahoo.com
}

\begin{abstract}
Samples were collected from seven of each bottle gourd and watermelon plants grown in Riyadh and Hail regions of Saudi Arabia in May, 2012 showing symptom suspected to be virus infection and analyzed by a double antibody sandwich against bottle gourd and watermelon viruses. Two of watermelon and three of bottle gourd samples were found to be positive with Cucumber green mottle mosaic virus (CGMMV). However, variable results were obtained with other viruses infecting cucurbits. One sample of CGMMV positive samples from each region were homogenized in a mortar separately and used to make mechanical inoculation on 25 plant species which produced characteristic symptoms of tobamo virus infection. Five ELISA-positive samples from naturally infection were further tested and detected by RT-PCR assay using virus specific primers that amplified a $400 \mathrm{bp}$ fragment in the coat protein gene. The nucleotide sequence of the PCR products from the Saudi isolates of CGMMV isolated from bottle gourd and watermelon were determined and demonstrated its similarity to the other isolates of CGMMV recorded in NCBI. The CP gene of CGMMV-Saudi Arabia isolates shared between $87.2 \%$ and 99.7\% identity in nucleotide level. The synthesized cDNA probe for CGMMV detection was hybridized with nucleic acid extracts from infected samples collected from the above mentioned locations. This is the first report regarding the genetic makeup of CGMMV at the molecular level in Saudi Arabia. (C) 2015 Friends Science Publishers
\end{abstract}

Keywords: CGMMV; ELISA; Indicator plants; RT-PCR; Hybridization; Sequence

\section{Introduction}

The main cultivated cucurbit species (cucumber (Cucumis sativus L.), watermelon (Citrullus lanatus L.), squash, (Cucurbita sp.), bottle gourd (Lagenaria siceraria), and melon ( $C$. melo L.) are important vegetable crops worldwide, especially in developing countries but are also subjected to more than 200 plant diseases.

Among these disease agents, viruses are most difficult to control and their aggressiveness depends on the host pathogen relationship and the impact of vector in the spread. Cucurbits have been reported to be infected with as many as 60 plant viruses worldwide (Nameth et al., 1986; Provvidenti, 1996; Zitter et al., 1996; Lecoq and Desbiez, 2012), at least 28 different viruses in were reported in Mediterranean region (Lecoq and Desbiez, 2012) and 15 of which were reported in Saudi Arabia (Al-Shahwan, 2003). Precise diagnosis has the prime importance in developing a management strategy of this virus. All these viruses have similar host range and thus cannot be used as a clue for the identification of the virus (Antignus et al., 2001; Yoon et al., 2002). CGMMV was originally described in the UK 1935 (Ainsworth, 1935). Thereafter reports were made in USA and Canada (Tian et al., 2014; Ling et al., 2014); Saudi Arabia (Al-Shahwan and Abdalla, 1992; Al-Saleh and Al-Shahwan, 1997); Iran (Moradi and Jafarpour, 2011), China and Greece (Zhang et al., 2009; Varveri et al., 2002), Korea and Myammar (Yoon et al., 2008; Kim et al., 2010), and in the Ukraine (Budzanivska et al., 2007). Several strains of CGMMV have been reported from Europe, Pakistan, India and Japan (Komuru et al., 1968; Lee, 1996; Antignus et al., 1990; Francki et al., 1986; Ugaki et al., 1991; Shim et al., 2005; Ko et al., 2006). CGMMV is mechanically and seed transmitted with a narrow host range comprising of cucurbits only and is different in host range from Tobacco mosaic virus (TMV) whose main hosts are members of the solanaceae (Antignus et al., 1990, 2001). CGMMV is a rod-shaped, microscopic (300 nm long x $18 \mathrm{~nm}$ wide) particle. The virus is easily sap and seed transmissible, and it survives for long periods in infected crop debris. This study aims to identification and characterization of CGMMV virus 
that was found infecting bottle gourd and watermelon grown in Riyadh and Hail regions, Saudi Arabia.

\section{Materials and Methods}

\section{Source of samples}

Seven suspected plants samples of each bottle gourd $(L$. siceraria), and watermelon ( $C$. lanatus) showing a mottling and mosaic symptoms were collected from Riyadh and Hail regions, Saudi Arabia in May, 2012. Samples were tested by DAS- ELISA (Agdia Inc., France and AC diagnostic, USA) as described by Clark and Adams, 1977, to detect the important cucurbits viruses infecting (Squash mosaic virus (SqMV), Cucumber mosaic virus (CMV), Watermelon mosaic virus (WMV), Alfalfa mosaic virus (AMV) Zucchini yellow mosaic virus (ZYMV) and CGMMV. One sample of CGMMV positive samples from each region isolated from bottle gourd and watermelon were homogenized in a mortar separately, after adding potassium phosphate buffer $(0.01 \mathrm{M}$ containing $0.1 \%$ sodium sulphite $\left(\mathrm{Na}_{2} \mathrm{SO}_{3}\right), \mathrm{pH} 7.2$ and applied on leaves of selected host range previously dusted with 600-mesh carburandum using the index finger according to Hill, 1984. Twenty five plant species were used in this test including: muskmelon (Cucumis melo cv. Russian), cucumber (Cucumis sativus cv. Beit Alpha), pumpkin (Cucurbita pepo subsp. pepo cv. Connecticut Field, C. lanatus cv. Sugar Baby, L. siceraria, Okeechobee gourd (Cucurbita okeechobeensis), Chenopodium amaranticolor Cost and Reyn, petunia hybrid, Squash (C. pepo cv. Vegetable Marrow), Datura stramonium, Nicotiana tabacum cvs. Samsun and Xanti-nc, N. glutinosa, N. benthamiana, N. rustica L., Solanum nigrum L., Vicia faba L., Raphanus sativs L., Brassica oleracea L., Beta vulgaris L, Phaseolus vulgaris cv. Black Turtel 2, Pisum sativum cv. Alska, Capsicum annuum L., Solanum lycopersicum and Luffa acutangula. Biological purification was carried out according to Kahn and Monroe, (1963) using $C$. amaranticolor as a local lesion host, whereas bottle gourd and watermelon were used as propagative host for the following experiments. Symptoms were recorded after three weeks at regular intervals and confirmation of viral infection was made through serological and molecular techniques. All plants showing no symptoms were assayed for virus infections by back inoculation of C. pepo, C. melo, C. sativus, C. lanatus and C. amaranticolor and by DAS-ELISA.

\section{Reverse Transcription-polymerase Chain Reaction (RT- PCR) Detection}

Five samples out of twelve CGMMV ELISA positive samples showing sever mottling and varying degree of mosaic were chosen as representative of the two main crops in Riyadh and Hail regions for molecular characterization. Total RNA was extracted from infected and uninfected bottle gourd and watermelon leaf samples using ISOLATE Plant RNA Mini Kit (BioLine Ltd, London, United Kingdom). The oligonucleotide primer (105 and 106) and RT-PCR condition were performed as described by (Varveri et al., 2002) using one step RT-PCR kit (Qiagen) in a Thermal cycler, Mastercycler® None gradient (Eppendorf, Germany). RT-PCR products were analyzed by electrophoresis in $1 \%$ agarose gel, visualized by ethidium bromide staining and 50 bp DNA ladder (Cat No. G4521, Promega) was used to determine the size of RT-PCR amplified products (Sambrook and Russell, 2001).

\section{Nucleotide Sequence and Analysis of CP Gene of the Saudi Isolates of CGMMV}

Amplified DNA fragments of expected size (400 bp) of partial coat protein gene of each isolate (RT-PCR positive samples) were purified using QIAquick Gel Extraction Kit (Qiagean). An RT-PCR product amplified by the CP genespecific primer of CGMMV-CP was cloned in pGEM-T easy vector (Promega Co). The nucleotide sequences were determined using an Applied Biosystems AB3730xI DNA Analyzer (Life Technologies Corporation, Carlsbad, California, USA) in the King Faisal Specialist Hospital Research Centre, Riyadh, KSA. The determined sequences of CGMMV isolates were subjected to a Blast-W search for comparison 25 previously reported CGMMV sequences, one of each of CFMMV, ZGMMV and KGMMV isolates at the GenBank databases as shown in Table 1. A phylogenetic tree and sequence homology were constructed using Laser gene DNASTAR, V5-05.

\section{Dot Blot Hybridization Assay}

The obtained RT-PCR product (400 bp) of partial CP gene of CGMMV-isolated from bottle gourd in Riyadh region were purified using QIAquick Gel Extraction Kit (Qiagean) and directly labeled with digoxigenin (DIG) labeling system according to (Feinberg and Vogelstein, 1983; Holtike and Kessler, 1990). Sap extractions were prepared from all collected samples from bottle gourd and watermelon by grinding according to (Laulhere and Rozier, 1976; Podleckis et al., 1993). The DNA was fixed on the membranes by Ultraviolet cross-linked for 30 sec. Prehybridization, hybridization and immunological detection were carried out using the DIG DNA labeling and Detection kit (Roche Diagnostics) according to the manufacturer's recommendation.

\section{Results}

\section{Virus Isolate and Host Range}

From Riyadh and Hail regions, twelve samples were detected to be positive by DAS-ELISA and five showing sever mottling and varying degree of mosaic were 
confirmed to be CGMMV positive by RT-PCR and nucleotide sequence. These samples including two samples collected from bottle gourd and one sample collected from watermelon in Riyadh region were designated as CGMMVSA-B1; CGMMV-SA-B2, and CGMMV-SA-W1 and two samples collected from each bottle gourd and watermelon in Hail region were designated as CGMMV-SA-B3, CGMMV-SA-W2, respectively. All five Saudi CGMMV samples produced systemic virus infection with similar symptoms on virus-inoculated $C$. melo cv. Russian, $C$. sativus cv. Beit Alpha, C. pepo subsp. pepo cv. Connecticut Field, $C$. lanatus cv. Sugar Baby, $L$. siceraria and $C$. okeechobeensis, while chlorotic local lesions developed on inoculated leaves of $C$. amaranticolor, and necrotic local lesions were recorded on P. hybrid (Fig. 1). But no evidence of infection was detected in C. pepo cv. Vegetable Marrow, D. stramonium, $N$. tabacum cvs. Samsun and Xanti-nc, $N$. glutinosa, $N$. benthamiana, $N$. rustica L., S. nigrum L., $V$. faba L., $R$. sativs $L$., B. oleracea L., B. vulgaris L, $P$. vulgaris cv. Black Turtel 2, P. sativum cv. Alska, $C$. annuит L. Symptomless systemic was observed in $S$. lycopersicum and L. acutangula. However, variable results were obtained when the samples were tested for the presence of other viruses including SqMV, CMV, WMV, AMV and ZYMV infecting cucurbits.

\section{RT-PCR}

The RT-PCR amplified product (400 bp) of CGMMV-CP from all five isolates infecting with CGMMV isolated from bottle gourd (SA-B1 and SA-B2), watermelon (SA-W1) plants, in Riyadh regions (lane 1, 2 and 3), CGMMV isolated from bottle gourd (SA-B3) and watermelon (SAW2) plants lanes (4 and 5) in Hail regions were obtained by using specific primer for CGMMV-CP gene, but no amplification from uninfected bottle gourd plants (lane 6) (Fig. 2).

\section{Generation of cDNA Probe and Dot Blot Hybridization for Detection of CGMMV}

A cDNA probe for CGMMV was synthesized using the 106 and 105 primer pair. Fig. 3 illustrate dot blot hybridization of total RNA extraction from naturally symptomatic bottle gourd and watermelon plant samples collected from Riyadh and Hail regions. (A), but no hybridization between the cDNA probe and nucleic acid extraction from uninfected bottle gourd plants (Lane B: 1). (Fig. 3).

\section{Sequence Analysis of the $400 \mathrm{bp}$ Fragment of CGMMV- CP Gene}

The DNA nucleotide sequences for the partial CP gene of the five Saudi CGMMV isolates from bottle gourd and watermelon plants from Riyadh and Hail regions have been determined. These five CGMMV sequences were compared with the already reported sequences in the Gene Bank by developing a phylogenetic tree of CGMMV, which showed

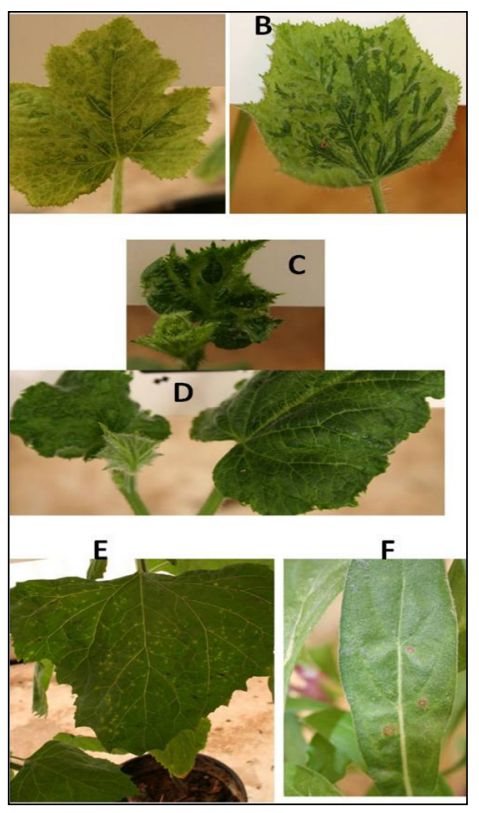

Fig. 1: Symptoms of CGMMV on some indicator plants developed in response to inoculation by the Saudi isolates of CGMMV in greenhouse condition. (A) and (B): Sever mottle on bottle gourd (L. siceraria), (C) and (D): Severe mosaic and blistering on cucumber (C. sativus), (E): chlorotic local lesion on Ch. amaranticolor, (F): Necrotic local lesion on $P$. hybrid

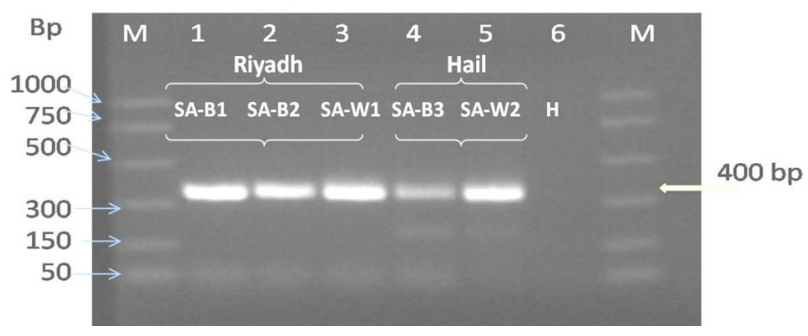

Fig. 2: Agarose gel electrophoresis $(1 \%)$ for RT-PCR amplified products (400 bp fragment) of the coat protein gene of CGMMV-SA isolates using specific primers. CGMMV isolated from bottle gourd (SA-B1 and SA-B2) and watermelon(SA-W1) plants, lanes (1, 2 and 3) from Riyadh region, CGMMV isolated from bottle gourd (SAB3) and watermelon (SA-W2) plants lanes (4 and 5) from Hail regions. No RT-PCR amplified product was observed with uninfected watermelon leaf (Lane 6). Arrow indicates PCR products of $400 \mathrm{bp}$. Lan M: $50 \mathrm{bp}$ PCR DNA marker (promega)

that Saudi isolates belong to four clusters, while make 2 clusters when compared to other cucurbit viruses like CFMMV, ZGMMV and KGMMV (Fig. 4 and 5).

The phylogenetic tree was determined for the Saudi as well as the other CGMMV isolates using the DNASTAR program. Comparing the nucleotide sequences for the five 
Table 1: Comparison of the nucleotide sequence identity of the coat protein gene of the Saudi isolates of CGMMV with those of other strains of the virus deposited in GenBank

\begin{tabular}{|c|c|c|c|c|c|c|c|c|}
\hline \multirow{3}{*}{ ACCESSION No. } & \multicolumn{5}{|c|}{ CGMMV Saudi isolates } & \multirow{3}{*}{ Isolate/Strain } & \multirow{3}{*}{ Original host } & \multirow{3}{*}{ Country } \\
\hline & CGMMV- & CGMMV-SA- & CGMMV-SA- & CGMMV-SA- & CGMMV-SA- & & & \\
\hline & SA-B1 & B2 & B3 & W1 & W2 & & & \\
\hline CGMMV-SA-B1 & $100 \%$ & $98.2 \%$ & $98.2 \%$ & $95.1 \%$ & $95.1 \%$ & SA-B1 & L. siceraria & Saudi Arabia \\
\hline CGMMV-SA-B2 & $98.2 \%$ & $100 \%$ & $100 \%$ & $95.4 \%$ & $95.4 \%$ & SA-B2 & L. siceraria & Saudi Arabia \\
\hline CGMMV-SA-B3 & $98.2 \%$ & $100 \%$ & $100 \%$ & $95.4 \%$ & $95.4 \%$ & SA-B3 & L. siceraria & Saudi Arabia \\
\hline CGMMV-SA-W1 & $95.1 \%$ & $95.4 \%$ & $95.4 \%$ & $100 \%$ & $100 \%$ & SA-W1 & C. lanatus & Saudi Arabia \\
\hline CGMMV-SA-W2 & $95.1 \%$ & $95.4 \%$ & $95.4 \%$ & $100 \%$ & $100 \%$ & SA-W2 & C. lanatus & Saudi Arabia \\
\hline NC-001801 & $93.6 \%$ & $95.4 \%$ & $95.4 \%$ & $98.8 \%$ & $98.8 \%$ & "SH" & - & Japan \\
\hline AB127937 & $93.9 \%$ & $93.9 \%$ & $93.9 \%$ & $97.9 \%$ & $97.9 \%$ & Pak & L. siceraria & Pakistan \\
\hline AB369274 & $95.1 \%$ & $94.2 \%$ & $94.2 \%$ & $98.2 \%$ & $98.2 \%$ & Watermelon & C. lanatus & South Korea \\
\hline AB447984 & $95.1 \%$ & $95.7 \%$ & $95.7 \%$ & $99.1 \%$ & $99.1 \%$ & KM4 & L. siceraria & South Korea \\
\hline AB447985 & $95.1 \%$ & $95.7 \%$ & $95.7 \%$ & $99.1 \%$ & $99.1 \%$ & KM7 & L. siceraria & South Korea \\
\hline AB510355 & $95.1 \%$ & $95.4 \%$ & $95.4 \%$ & $99.4 \%$ & $99.4 \%$ & M17C & L. siceraria & Myanmar \\
\hline AF225984 & $95.1 \%$ & $95.7 \%$ & $95.7 \%$ & $99.1 \%$ & $99.1 \%$ & CGMMV-W(K) & C. lanatus & Korea \\
\hline AF417243 & $94.8 \%$ & $95.7 \%$ & $95.7 \%$ & $98.8 \%$ & $98.8 \%$ & KOM & C. melo & Korea \\
\hline AJ243831 & $94.5 \%$ & $95.4 \%$ & $95.4 \%$ & $98.8 \%$ & $98.8 \%$ & CGMMV-NS & - & Korea \\
\hline AJ429090 & $93.3 \%$ & $94.8 \%$ & $94.8 \%$ & $98.8 \%$ & $98.8 \%$ & - & - & France \\
\hline AJ459422 & $95.1 \%$ & $92.7 \%$ & $92.7 \%$ & $93.0 \%$ & $93.0 \%$ & GR5 & C. lanatus & Greece \\
\hline AJ459423 & $95.4 \%$ & $95.4 \%$ & $95.4 \%$ & $99.4 \%$ & $99.4 \%$ & GR7 & C. lanatus & Greece \\
\hline AJ748352 & $94.2 \%$ & $95.7 \%$ & $95.7 \%$ & $99.7 \%$ & $99.7 \%$ & AL1 & L. siceraria & India \\
\hline DQ767636 & $93.3 \%$ & $94.5 \%$ & $94.5 \%$ & $99.1 \%$ & $99.1 \%$ & - & L. siceraria & India \\
\hline EF521882 & $93.9 \%$ & $92.7 \%$ & $92.7 \%$ & $93.6 \%$ & $93.6 \%$ & MC-1 & C. sativus & Russia \\
\hline EU366912 & $94.8 \%$ & $94.2 \%$ & $94.2 \%$ & $97.9 \%$ & $97.9 \%$ & Bangalore & - & India \\
\hline FJ654658 & $94.5 \%$ & $95.4 \%$ & $95.4 \%$ & $98.8 \%$ & $98.8 \%$ & $\mathrm{C}$ & C. sativus & Taiwan \\
\hline GQ500898 & $94.5 \%$ & $95.1 \%$ & $95.1 \%$ & $98.5 \%$ & $98.5 \%$ & SDAU-TANG & C. реро & China \\
\hline HМ008919 & $94.5 \%$ & $95.1 \%$ & $95.1 \%$ & $98.5 \%$ & $98.5 \%$ & CCMV-TANG & C. реро subsp. реро & China \\
\hline HM363013 & $94.5 \%$ & $95.1 \%$ & $95.1 \%$ & $98.5 \%$ & $98.5 \%$ & Yunnan & C. lanatus & China \\
\hline HQ329106 & $93.6 \%$ & $93.9 \%$ & $93.9 \%$ & $98.5 \%$ & $98.5 \%$ & Kalat & C. sativus & Iran \\
\hline HQ692886 & $95.1 \%$ & $95.7 \%$ & $95.7 \%$ & $99.1 \%$ & $99.1 \%$ & CGMMV11 & L. siceraria & Taiwan \\
\hline JF432067 & $87.2 \%$ & $87.5 \%$ & $87.5 \%$ & $90.9 \%$ & $90.1 \%$ & Wh1 & Zea maize & China \\
\hline JF838188 & $94.8 \%$ & $95.4 \%$ & $95.4 \%$ & $98.8 \%$ & $98.8 \%$ & Byungchun & C. sativus & South Korea \\
\hline JN605350 & $94.8 \%$ & $95.4 \%$ & $95.4 \%$ & $98.8 \%$ & $98.8 \%$ & GD-GZ & C. sativus & China \\
\hline NC-002633 & $49.4 \%$ & $49.4 \%$ & $49.4 \%$ & $48.8 \%$ & $48.8 \%$ & CFMMV & - & Israel \\
\hline NC-003878 & $52.5 \%$ & $52.5 \%$ & $53.6 \%$ & $52.6 \%$ & $52.6 \%$ & ZGMMV-K & - & South Korea \\
\hline AB015145 & $50.9 \%$ & $50.9 \%$ & $52.1 \%$ & $51.0 \%$ & $51.0 \%$ & KGMMV-Yodo & - & Japan \\
\hline
\end{tabular}

Saudi isolates indicated similarity between them that ranged between $95.1 \%$ and $100.0 \%$. Similarity was also found between the five Saudi Arabian isolates and the remainder of the CGMMV isolates that were obtained from GenBank that ranged between $87.2 .0 \%$ and $99.7 \%$. Similarity was found between Saudi isolates SA-W1 and SA-W2 isolates and the rest of the other CGMMV isolates in a range of $90.1 \%$ to $99.7 \%$ identical for them. The results showed that the nucleotide sequence of CGMMV-SA-W1 and W2 isolates shared a high sequence identity $(99.7 \%)$ with CGMMV-AL1 isolate isolated from $L$. siceraria from India (AJ748352), (99.4\%) with M17C and GR7 from Myanmar (AB510355) and Greece (AJ459423), 99.1\% with CGMMV-W (K) from Korea (AF225984), KM4 and KM7 from South Korea (AB447984 and AB447985) and CGMMV11 from Taiwan (HQ692886) while, low sequence identities (93\% to $98.5 \%$ ) were observed between our isolates and other isolates of CGMMV isolated from different countries (Table 1). The results showed that the nucleotide sequence of CGMMVSA-B1, SA-B2 and SA-B3 isolates shared a hight sequence identity $(95.7 \%)$ with CGMMV-KM4, KM7 isolated from L. siceraria from South Koreaa and CGMMV-WK and KOM isolates isolated from $C$. lanatus and $C$. melo respectively from Korea. Low sequence identities $(92.7 \%$ to $98.5 \%)$ were served with other isolates of CGMMV from isolated from different countries. Sequence homology with ZGMMV, KGMMV and CFMMV was lowest at about 48.8 to $53.6 \%$. The nucleotide sequences of the partial $\mathrm{CP}$ genes of CGMMV-SA (CGMMV-SA-B1, CGMMV-SA-B2, CGMMV-SA-B3, CGMMV-SA-W1 and CGMMV-SAW2) isolate (GenBank Accession No., KC295228, KC295229, KC295230, KC295231 and KC295232) respectively (Table 1).

\section{Discussion}

CGMMV has been reported from few Mediterranean countries: France, Greece, Israel, Spain, and Syria (Avgelis and Vovlas, 1986; Antignus et al., 1990; Blancard et al., 1994; Celix et al., 1996; Varveri et al., 2002; Kassem et al., 2005). In Saudi Arabia, a severe infection outbreak was observed on watermelon and bottle gourd crops (AlShahwan and Abdalla, 1992; Al-Saleh and Al-Shahwan, 1997). The tobamovirus, CGMMV causes severe disease of cucurbits worldwide. The typical symptoms in watermelon 


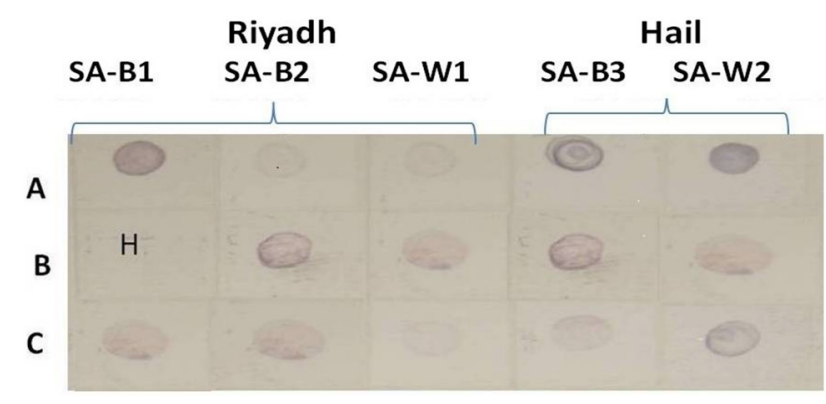

Fig. 3: Dot blot hybridization for detection of CGMMVSA isolated from bottle gourd (SA-B1 and SA-B2), and watermelon plants (SA-W1) from Riyadh region, bottle gourd (SA-B3) and watermelon (SA-W2) plants from Hail region. No hybridization reaction was observed with uninfected watermelon leaves (Lane B: H)

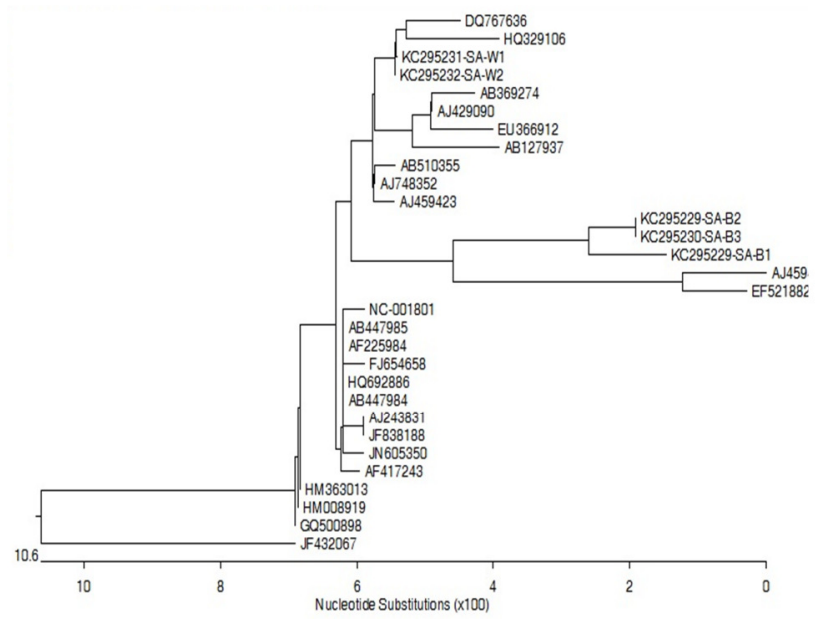

Fig. 4: Phylogenetic tree constructed from the alignment of nucleotide sequences of coat protein gene between CGMMV Saudi isolates and 25 CGMMV isolates, obtained from the GenBank database using Laser gene DNASTAR, V5-05

including leaf mottling and mosaic have been reported in greenhouse-grown plants (Varveri et al., 2002; Shim et al., 2005), but these symptoms are masked in plants growing in open fields (Reingold et al., 2013). Serological testing by ELISA of a large number of fruits exhibiting systemic mosaic and mild to severe yellow mottling symptoms, confirmed the presence of CGMMV. Differences were observed among CGMMV isolates in their response to differential hosts (Boubourakas et al., 2004). Serological and molecular variability has also been reported between European and Asian isolates.

Immunodiffusion test in agar plates was also used for detection of CGMMV isolated from infected bottle gourd plants using specific antiserum (Alshahwan and Abdalla, 1992). Although all samples showed systemic mosaic and mild to severe yellow mottling symptoms, only $41.6 \%$ of

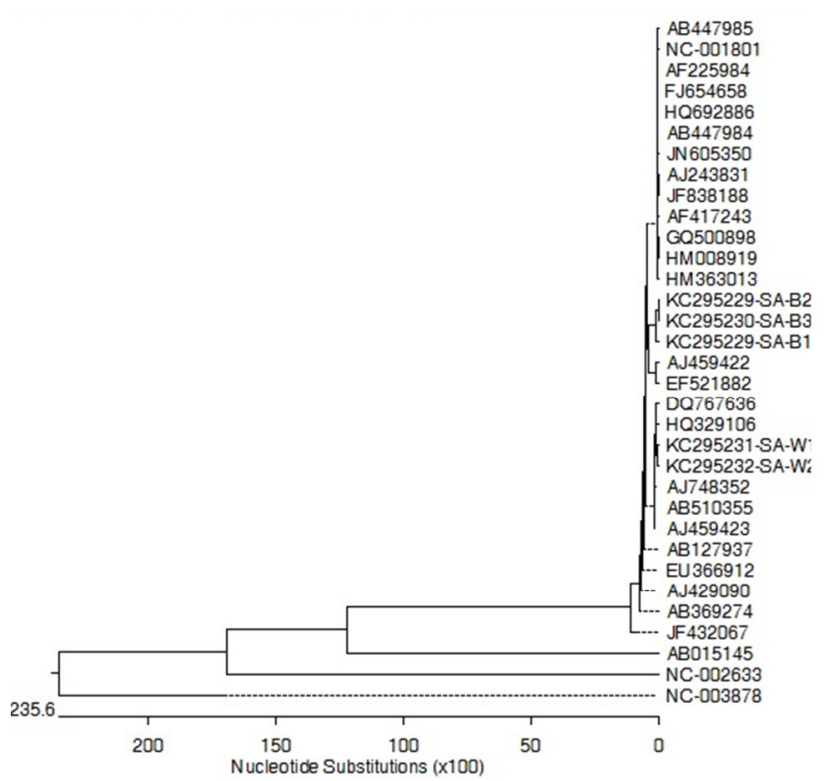

Fig. 5: Phylogenetic tree constructed from the alignment of nucleotide sequences of coat protein gene between CGMMV Saudi isolates and 25 CGMMV isolates, one of CFMMV, two of ZGMMV and three of KGMMV isolates obtained from the GenBank database using Lasergene DNASTAR, V5-05

samples were infected with CGMMV. This percentage might be due to the fact that mottle mosaic is a complex disease that can be caused by different viruses such as CMV, WMV-2, SqMV, ZYMV, as well as by CGMMV (Shabanian et al., 2007; Moradi and Jafarpour, 2011) and the symptoms observed are as a result of multiple infection.

Several molecular techniques have been tested, for the identification of CGMMV. Among those detection methods, RT-PCR (Ugaki et al., 1991; Shim et al., 2005; Yoon et al., 2008; Liu et al., 2009), real time RT-PCR (Chen et al., 2008), transmission electron microcopy (Alshahwan and Abdalla, 1992), immune capture-RTPCR (Celix et al., 1996), ELISA (Antignus et al., 1990; Celix et al., 1996; Mitsuhiro et al., 2006) and monoclonal antibodies (Antignus et al., 2001). To establish procedure of identification and detection, mechanical inoculation, DASELISA, RT-PCR, molecular hybridization and nucleotide sequence were applied in this study. The present study demonstrates the successful use of RT-PCR and sequencing to directly detect CGMMV in infected watermelon and bottle gourd plants for the first time in Saudi Arabia.

A non-radioactive dot-blot hybridization technique have been used to detect several plant viruses and have been shown to be more sensitive and more specific than serology (Hseu et al., 1987; Hahm et al., 1993; James et al., 1999; Gioconda et al., 2000; Lee et al., 2001; Liu et al., 2007).

In conclusion, five CGMMV isolates affecting bottle gourd and watermelon plants in Saudi Arabia were 
determined based on biological reactions, RT-PCR, partial nucleotide sequences of CP gene and demonstrated its similarity. Data shown in this study represent the first report on the characterization of CGMMV at the molecular level in Saudi Arabia and will be helpful in developing effective control strategies for this virus.

\section{Acknowledgments}

The author gratefully acknowledges the financial support by the Agricultural Research Center, Deanship of Scientific Research of, King Saud University, Riyadh. A special thank also to Dr. M.A. Al-Saleh at Plant Protection Department, College of Food and Agricultural Sciences, King Saud University, for useful advice and suggestion.

\section{References}

Ainsworth, G.C., 1935. Mosaic disease of cucumber. Ann. Appl. Biol., 22: $55-67$

Al-Saleh, M.A. and I.M. Al-Shahwan, 1997. Viruses Infecting Cucurbits in Riyadh, Gassim and Hail Regions of Saudi Arabia. Arab Gulf J. Sci. Res., 15: 223-254

Al-Shahwan, I.M., 2003. Host Index and Status of Plant Viruses and VirusLike Disease Agents in Saudi Arabia, pp: 5-27. Res. Bult., No. 121, Agric. Res. Center, King Saud University, Saudi Arabia

Al-Shahwan, I.M. and O.A. Abdalla, 1992. A strain of Cucumber green mottle mosaic virus (CGMMV) from Bottegourd in Saudi Arabia. $J$. Phytopathol., 134: 152-156

Antignus, Y., M. Pearlsman, R. Ben-Yoseph and S. Cohen, 1990 Occurrence of a variant of Cucumber green mottle mosaic virus in Israel. Phytoparasitica, 18: 50-56

Antignus, Y., Y. Wang, M. Pearlsman, O. Lachman, N. Lavi and A. GalOn, 2001. Biological and molecular characterization of a new cucurbit-infecting tobamovirus. Phytopathology, 91: 565-557

Avgelis, A.D. and C. Vovlas, 1986. Occurrence of Cucumber green mottle mosaic virus in the island of Crete (Greece). Phytopathol. Mediterr. 25: $166-168$

Blancard, D., H., Lecoq and M. Pitrat, 1994. A Colour Atlas of Cucurbit Diseases. Manson Publishing, London, UK

Boubourakas, I.N., E. Hatziloukas, Y. Antignus and N.I. Katis, 2004. Etiology of leaf chlorosis and deterioration of the fruit interior of watermelon plants. J. Phytopathol., 152: 580-588

Budzanivska, I.G., T.O. Rudneva, T.P. Shevchenko, I. Boubriak and V.P. Polischuk, 2007. Investigation of Ukrainian isolates of Cucumber green mottle mosaic virus. Arch. Phytopathol. Plant Prot., 40: 376-380

Celix, A., M. Luis-Arteaga and E. Rodriguez-Cerezo, 1996. First report of Cucumber green mottle mosaic Tobamovirus infecting greenhousegrown cucumber in Spain. Plant Dis., 80: 1303

, H.Y., W.J. Zhao, Q.S. Gu, Q. Chen, S.M. Lin and S.F. Zhu, 2008. Real timeTaqMan RT-PCR assay for the detection of Cucumber green mottle mosaic virus. J. Virol. Methods, 149: 326-329

M.F. and A.N. Adams, 1977. Characteristics of the microplate method of enzyme-Linked immunosorbent assay for the detection of plant viruses. J. Gen. Virol., 34: 475-483

Feinberg, A.P. and B. Vogelstein, 1983. A technique for radiolabelling DNA restriction endonuclease fragments to high specific activity. Anal. Biochem., 132: 6-13

Francki, R.I.B., J. Hu and P. Palukaitis, 1986. Taxonomy of cucurbitinfecting Tobamovirusas determined by serological and molecular hybridization analyses. Intervirology, 26: 156-163

Gioconda, N., S.S. Ben, A.A. Marı'a, R. Luis, G. Jose and M. Pedro, 2000. A new procedure to differentiate Citus tristeza virus isolates by hybridization with digoxigenin-labeled cDNA probes. J. Virol. Methods, 85: 83-92
Hahm, Y.I., K.S. Choi, Y.S. Kim, J.K. Choi, S.W. Bae and Y.S. Hwang, 1993. Hybridization detection of potato viruses using digoxigeninlabeled RNA probe. RDA J. Agric. Sci., 35: 239-244

Hill, S.A., 1984. Methods in Plant Virology: Methods in Plant Pathology, Vol 1, p: 167. Oxford, ReinoUnido, Blackwell Scientific

Holtike, H.J. and C. Kessler, 1990. Non-radioactive labeling of RNA transcripts in vitro with the hap ten digoxigenin (DIG): hybridization and ELISA -based detection. Nucleic Acids Res., 18: 5843-5851

Hseu, S., C. Huang, C. Chang, W. Yang, Y. Chang and C. Hsiao, 1987. The occurrence of five viruses in six cucurbits in Taiwan. Plant Prot. Bull., 29: 233-244

James, D., W. Jelkmann and C. Upton, 1999. Specific detection of Cherry mottle leaf virus using digoxigenin-labeled cDNA probes and RTPCR. Plant Dis., 83: 235-239

Kahn, R.P. and R.I. Monroe, 1963. Detection of tobacco veinal necrosis (strain of potato virus Y) in Solanum carensaii and S. andigenum introduce into the United States. Phytopathology, 53: 1356-1359

Kassem, A.A.H., K.A. Halim, O.E.G. Rifai and W. Warrak, 2005. The most important viruses affecting cucurbits in Syria. Arab J. Plant Prot., 23: $1-6$

Kim, O.K., T. Mizutani, K.T. Natsuaki and K. Soe, 2010. First report and the genetic variability of Cucumber green mottle mosaic virus occurring on bottle gourd in Myanmar. J. Phytopathol., 158: $572-575$

Ko, S.J., Y.H. Lee, K.H. Cha, S.H. Lee, H.S. Choi, Y.S. Choi, G.C. Lim and K.H. Kim, 2006. Incidence and distribution of virus disease on cucumber in Jeonnam procince during 1999-2002. Plant Pathol. J. 22: $147-151$

Komuru, Y., H. Tochihara, R. Fukatsu, Y. Nagai and S. Yoneyama, 1968. Cucumber green mottle mosaic virus on watermelon in Chiba and Ibaraki Prefectures (in Japanese). Ann. Phytopathol. Soc. Jpn., 34: 377

Laulhere, J.P. and C. Rozier, 1976. One step extraction of plant nucleic acids. Plant Sci. Lett., 6: 237-242

Lecoq, H. and C. Desbiez, 2012. Viruses of Cucurbit Crops in the Mediterranean Region. An Ever- Changing Picture. Adv. Virus Res., 84: $67-126$

Lee, I.M., L.A. Lukaesko and C.J.M. Maroon, 2001. Comparison of diglabeled PCR, nested PCR and ELISA for the detection of Clavibacter michiganensis subsp. sepedonicus in field grown potatoes. Plant Dis., 85: 261-266

Lee, K.Y., 1996. Current occurrence and control of CGMMV 'Konjak' disease. Plant Dis. Agric., 2: 28-39

Ling, K.S., R. Li and W. Zhang, 2014. First Report of Cucumber green mottle mosaic virus Infecting Greenhouse Cucumber in Canada. Plant Dis., 98: 701

Liu, Y., B. Sun, X. Wang C. Zheng and G. Zhou, 2007. Three digoxigeninlabeled cDNA probes for specific detection of the natural population of Barley yellow dwarf viruses in China by dot-blot hybridization. $J$. Virol. Methods, 145: 22-29

Liu, Y., Y.N. Wang, X.F. Wang and G.G. Zhou, 2009. Molecular characterization and distribution of Cucumber green mottle mosaic virus in China. J. Phytopath., 157: 393-399

Mitsuhiro, S., O. Takayoshi and S. Yoshiteru, 2006. A new source of Resistance to Cucumber green mottle mosaic virus in melon. J. Jpn. Soc. Hortic. Sci., 75: 469-475

Moradi, Z. and B. Jafarpour, 2011. First Report of Coat Protein Sequence of Cucumber Green Mottle Mosaic Virus in Cucumber Isolated from Khorasan in Iran. Int. J. Virol., 7: 1-12

Nameth, S.T., J.A. Dodds, A.O. Paulus and F.F. Laemmlen, 1986. Cucurbit viruses of California: an ever-changing problem. Plant Dis., 70: 8-11

Podleckis, E.V., R.W. Hammond, S.S. Hurtt and A. Hadidi, 1993 Chemiluminescent detection of potato and pome fruit viroids by digoxigeninlabelled dot blot and tissue blot hybridization. J. Virol. Methods, 43: 147-158

Provvidenti, R., 1996. Diseases caused by viruses. In: Compendium of Cucurbit Diseases, pp: 37-45. T.A. Zitter, D.L. Hopkins and C.E. Thomas (eds.). American Phytopathological Society, St. Paul, Minnesota, USA 
Reingold, V., O. Lachman, A. Koren and A. Dombrovsky, 2013. First report of Cucumber green mottle mosaic virus (CGMMV) symptoms in watermelon used for the discrimination of nonmarketable fruits in Israeli commercial fields. New Dis. Reports, 28: 11

Sambrook, J. and D.W. Russell, 2001. Molecular Cloning: A Laboratory Manual, $3^{\text {rd }}$ edition. Cold Spring Harbor Laboratory. Cold Spring Harbor, New York, USA

Shabanian, M., H. Masomi, A. Hoseinipour, J. Heidarnejad and Z. Azami, 2007. Identification and distribution of cucumberinfecting viruses in the jiroft greenhouses and partial characterization of Zucchini yellow mosaic virus collected from this region. J. Sci. Technol. Agric. Nat. Resour., 11: 393-406

Shim, C.K., K.S. Han, J.H. Lee, D.W. Bae, D.K. Kim and H.K. Kim, 2005. Isolation and charatracterization of watermelon isolate of Cucumber green mottle mosaic virus (CGMMV-HY1) from watermelon plant with severe mottle mosaic symptoms. Plant Pathol. J., 21: 167-171

Tian, T.K. Posis, C.J. Maroon-Lango, V. Mavrodieva, S. Haymes, T.L. Pitman and B.W. Falk, 2014. First Report of Cucumber green mottle mosaic virus on Melon in the United States. Dis. Notes, 98: 8,1163
Ugaki, M., M. Tomiyama, T. Kakutani, S., Hidaka, T. Kiguchi, R. Nagata, T. Sato, F. Motoyoshil and M. Nishiguchi, 1991. The complete nucleotide sequence of Cucumber green mottle mosaic virus (SH strain) genomic RNA. J. Gen. Virol., 72: 1487-1495

Varveri, C., N. Vassilakos and F. Bem, 2002. Characterization and detection of Cucumber green mottle mosaic virus in Greece. Phytoparasitica, 5: 493-501

Yoon, J.Y., B.E. Min, J.K. Choi and K.H. Ryu, 2002. Genome structure and production of biologically active in vitro transcripts of cucurbitsinfecting Zucchini green mottle mosaic virus. Phytopathology, 92: 156-163

Yoon, J.Y., G.S. Choi, S.K. Choi, J.S. Hong, J.K. Choi, W. Kim, G.P. Lee and K.H. Ryu, 2008. Molecular and biological diversities of Cucumber green mottle mosaic virus from cucurbitaceous crops in Korea. J. Phytopath., 156: 408-412

Zhang, Y., J. Li and M.F. Li, 2009. Occurrence of Cucumber green mottle mosaic virus on Cucurbitaceous Plants in China. Plant Dis., 93: 200

Zitter, T.A., D.L. Hopkins and C.E. Thomas, 1996. Compendium of Cucurbit Diseases, pp: 37-45. The American Phytopathological Society, Minnesota, USA

(Received 04 September 2014; Accepted 24 November 2014) 